\title{
Economic Growth and Automation Risks in Developing Countries Due to the Transition Toward Digital Modernity
}

\author{
Aki Nagano \\ Kyoto city \\ Japan \\ ngnak2017@gmail.com
}

\begin{abstract}
${ }^{\mathbf{1}}$
This paper is aimed at making recommendations to establish a stewardship to embody the responsibilities and morality that will prevent the automation risks faced by Least Development Countries (LDCs) due to transition toward digital modernity. Recent studies reveal that law qualified individuals in developed countries will face the risks of jobs that are highly subject to automation. This indicates that corresponding risks will be seen in LDCs. The rise of digitalization may override developing country's opportunities to elevate itself from a low-income country to a middle or high-income country. In the aftermath of World War II, western society tried to support LDCs in maintain the principles of a free world system and contribute to reducing poverty through market oriented development. Since the end of Cold War, defense of the free world has lost its significance but economy is getting more important political instrument. Advancement of automation technologies might aggravate opportunities for developing country's economic growth and international society needs the alternative principles.
\end{abstract}

\section{CCS CONCEPTS}

- Social and professional topics $\rightarrow$ Computing and business; employment issues, automation, economic impact • Applied computing $\rightarrow$ Law, Social, and Behavioral Science; Economics, Sociology

\section{KEYWORDS}

development economy, automation risks, stewardship, transition studies, global governance, digital modernity

\footnotetext{
${ }^{1}$ Permission to make digital or hard copies of all or part of this work for personal or classroom use is granted without fee provided that copies are not made or distributed for profit or commercial advantage and that copies bear this notice and the full citation on the first page. Copyrights for components of this work owned by others than ACM must be honored. Abstracting with credit is permitted. To copy otherwise, or republish, to post on servers or to redistribute to lists, requires prior specific permission and/or a fee. Request permissions from Permissions@acm.org.
}

\begin{abstract}
ACM Reference format:
A. Nagano. 2018. Economic Growth and Automation Risks in Developing Countries Due to the Transition Toward Digital Modernity. In Proceedings of the $11^{\text {th }}$ International Conference on Theory and Practice of Electronic Governance, Galway, Ireland, April 2018 (ICEGOV'18), 9 pages.

DOI: $10.1145 / 3209415.3209442$
\end{abstract}

\section{INTRODUCTION}

The transition toward digital modernity with the fourth industrial revolution will provide huge benefits to our society. These benefits can potentially change industry, business, people's lifestyles, the education system, and so on. However, the negative factors of the revolution, such as unemployment risks and gender problems, have also been reported [1-5] Solutions such as the introduction of a basic income, short-term labor, a robotics tax, educational improvements, etc. are being actively debated on various media such as the Internet, newspaper, SNS, and in academia. However, these are mainly the preserve of advanced countries, which have the ability to deal with the risks of digitalization and the automation. Although developing countries will be subject to the damages, effective countermeasures are not apparent yet. In addition, the fourth industrial revolution will have an impact on the economic development typically the East and Southeast Asian economic model. This is also a critical issue for the field of international aid because East and Southeast Asian economic growth have contributed remarkably to the reduction in poverty. The transition toward the fourth industrial revolution may have meant that the LDCs have lost the opportunities to break out of the vicious cycle of poverty. It is necessary for the international community to take responsibility for the issue. The aim of this paper is to make recommendations to establish a stewardship to embody the responsibilities and morality that will prevent the automation risks faced by LDCs.

ICEGOV '18, April 4-6, 2018, Galway, Ireland (c) 2018 Association for Computing Machinery. ACM ISBN 978-1-4503-5421-9/18/04...\$15.00 https://doi.org/10.1145/3209415.3209442 
This study begins by briefly summarizing previous research focusing on the risks in the era of the fourth industrial revolution. In the third section, it describes the characteristics of the regional exports and the fourth section examines how economic growth contributed to poverty reduction in East and Southeast Asian economies and addresses the background factors of their economic growth and political relationship to Western foreign policy and ends with a brief discussion of the responsibilities of the international community for developing countries regarding the risks of digitalization and automationrelated issues.

\section{RISKS IN THE ERA OF THE FOURTH INDUSTRIAL REVOLUTION}

Human society has experienced three industrial revolutions. The first industrial revolution occurred in England from the 1750 s to the 1870 s. The mechanization of water and the steam engine promoted efficiencies of production and contributed to the trilateral trade under colonization. The second industrial revolution occurred from 1945 to the mid-1970s. At this time, world hegemony shifted from the European countries to the United States. A new production system called "Taylorism" was invented. It also symbolized mass production and intensive labor. The other driving forces during this era were internal combustion engines, telephones, home appliances, and electric energy. They dramatically changed people's life styles. During the 1970 s to 1990 s, the so-called "computation age" began. Electronics and IT were critical in manufacturing systems. This phase also witnessed the end of the Cold War, which significantly affected the political and economic landscape globally. It is obvious that the history of industrial revolutions has been accompanied by the beginning of world trade and the rise of globalization from the very start. Moreover, from the first industrial revolution to the third industrial revolution, the economy periodically underwent repeated convergence and divergence and was not able to sustain stable economic growth. Gordon (2015) explained this based on the theory that great innovations consist of original inventions and subsidiary subinventions where original inventions are seeds for subinventions [6]. These corresponded to the economic cycle, and economic growth only continued until it reached the end of improvement subinventions. If that is so, when is the beginning of the next industrial revolution? Brynjolfsson et al. $(2011,2014)$ pointed out that 2006 was an initial year for " the second machine age", in which computer performance reached a different dimension caused by exponential technological progress following Moore's Law[7-8]. This indicates that the fourth industrial revolution has already begun.

In 2011, the German government started the project known as "Industry 4.0". The vision is to increase the digitization of production [9] and promote cyber physical systems. The aim is that a German industrial standard will lead to control of global manufacturing systems. Industry 4.0 is ushering in a fourth industrial revolution [10]. In other countries, various national projects are being conducted: the US administration launched the Advanced Manufacturing Partnership (AMP) between government, universities, and enterprises in 2011. The aim of AMP is to create middle class jobs and economic growth through strengthening the manufacturing sectors and innovations [11]; China established "Made in China 2050", which consists of strategies to upgrade Chinese manufacturing industry. The aims are industrial structural adjustment, improvement in labor productivity, innovation-oriented organization formation, progress in industrialization and information conversion, and producing eco-products and environmentally friendly production processes [12]; the EU established the project "Action Plan $\mathrm{T}$ " and suggested a roadmap for manufacturing 2.0 under the European Commission's EU2020 strategy. The aim is to promote a better use of information and communication technology (ICT) for manufacturing [13]. The action plan involves the five $R \& D$ research clusters, namely, agile manufacturing systems and processes, seamless factory lifecycle management, customers in-the loop, people at the forefront, and collaborative supply network [13]; In England, catapult centers play a key role in promoting innovations. According to Innovate UK, there are 11 catapult centers, which are cell and gene therapy, compound semiconductor applications, digital, energy system, future cities, high value manufacturing, medicine discovery, off shore renewable energy, precision medicine, satellite applications, and transport system [14]. These are designed to transfer academic achievements into commercial success by promoting economic growth [15]; The French government has promoted the project, "Industry of the Future", which aims to see all companies modernize their production bases and use digital technologies to transform the business model [16]; In Japan, the strategy for the fourth industrial revolution is related to the "Japan revitalization strategies 2016", " new robot strategies" and "Society 5.0". The aims are to enforce economic growth [17]. At the same time, as Japanese society faces issues in longevity, low birth rate, and a decreasingly productive aging population, the usages of robotics are expected to deal with these issues [18].

Most government's strategies for the fourth industrial revolution are likely to lie in the public private partnerships, where technological innovations are anchored in private firms. Global digital companies especially such as Google, Microsoft, APPLE, IBM and Amazons have been leaders in technological innovations and developed autonomous vehicles, Artificial Intelligence, humanized robots and biological engineering, etc. Based on fully funded capitals and human resources, they have also invested in start-up companies, universities, and research institutions, and acqui-hire them. The role of the private sector is becoming important in the fourth industrial revolution.

The fourth industrial revolution is the ongoing technological revolution. Table 1 presents the Schwab's definition of the fourth industrial revolution as physical (autonomous vehicles, 3D printing, robotics), digital (the Internet of Things, Artificial Intelligence, sensors, VR, Bitcoin, block chain), and biological (human genome, IPS cell tissue engineering, synthetic biology, gene editing, CRISPR)[3]. These clusters are deeply interrelated 
Economic Growth and Automation Risks in Developing Countries Due to the Transition Toward Digital Modernity

to create various technological benefits based on their progress and associated discoveries [3]. The technological advancements will confer tremendous benefits.

Table 1: Three clusters of the fourth industrial revolution modified by Schwab (2016) [3]

\begin{tabular}{lll}
\hline \multicolumn{1}{c}{ Physical } & \multicolumn{1}{c}{ Digital } & \multicolumn{1}{c}{ Biological } \\
\hline $\begin{array}{l}\text { Autonomous } \\
\text { vehicles }\end{array}$ & $\begin{array}{l}\text { Internet of } \\
\text { Things }\end{array}$ & $\begin{array}{l}\text { Human Genome } \\
\text { project }\end{array}$ \\
& $\begin{array}{l}\text { Artificial } \\
\text { Intelligence }\end{array}$ & $\begin{array}{l}\text { IPS Cell tissue } \\
\text { engineering }\end{array}$ \\
$\begin{array}{l}\text { 3D printing } \\
\text { Advanced }\end{array}$ & Sensors & $\begin{array}{l}\text { Synthetic biology } \\
\text { robotics }\end{array}$ \\
New materials & VR editing \\
& block chain & CRISPR \\
\hline
\end{tabular}

For example, autonomous vehicles will create safe and secure transportation systems. 3D printing is appropriate for producing intricate three-dimensional objects and mainly used for creating prototypes in various sectors, such as manufacturing, medicine, art, aerospace, household uses, and so on. The progress of robotics has also been obtained through remarkable innovation. For example, Baxter produced by Rethink Robotics is known for its progressiveness and uniqueness. The key characteristic of Baxter is that it is designed to move its body based on training not for programming [19]. HAL produced by Cyberdyne is another type of robot. It is a cyborg robot merging functions between the machine, human body, and information [20] and it mainly works as a personal assistants. Rumba produced by irobot is also categorized as a human assistant [21]. It is a home appliance that works as an automated cleaner. Nano robot works in the medical fields and investigates inside of the body. It is an autonomous machine, which at the scale of $10^{-9}$ meters can diagnose and treat human diseases at the cellular level [22]. In the cluster of the digital technologies, the progress of the Internet of Things (IoT) is remarkable. It has defined the ubiquitous system whereby various things are networked and receive information through sensors and control signals. Artificial Intelligence (AI) is defined as a system that artificially recreates the functions of the human brain and nerve system such as memory, inference, judgment, learning, etc. It is substantially identical to operate human brain. Nowadays, AI is widely used in the products such as drones, autonomous cars, robots, and so on. When used in combination with IoT, AI and robotics especially can exert positive effects. The next notable innovation is the block chain. It is a digitally distributed ledger, which is verified through a cryptographic "private key" [22]. Its initial purpose was to provide a secure digitalized transferring system for the Bit-coin. However, applications such as voting systems, organizational management, trading, copyright protection, banking, accounting, authentication systems and so
ICEGOV'18, April 2018, Galway, Ireland

on are expanding. In a biological field, the human genome, IPS cell tissue engineering, synthetic biology, and gene editing will contribute to the treatment of intractable diseases. For example, CRISPR is a gene editing technology[23]. Using this technique, many researchers have conducted research on the repairing genetic mutations causing blindness, inhibiting the proliferation of cancer cells, and creating cells that are resistant to infection, making wheat tolerant of fungi-causing disease, and so on [24]. Another application is living modified organisms. OXITEC is used in the gene engineering to control transmitting insects [25]. The commercial uses are expanding. The induced pluripotent stem (iPS) cell is mainly used to regenerate medicine for organs and tissues [26]. Combining multiple technologies is also effective for use in biological innovations. For example, a group of researchers at Kyoto University and Samgamo conducted genetic treatment methods for serious diseases such as muscular dystrophy and AIDs based on the usages of CRISPR, iPS, and cell transplantation techniques [24].

However, there are both good and bad sides to these development, especially with technological innovations in manufacturing and the service sector. Frey and Osborne (2013) investigated the automation of job risks based on the occupation-based approach [1]. They estimated that about $47 \%$ of total U.S employment is at risk [1]. Following Frey and Osborne's work, the OECD applied a task-based approach to analyze the "automatability" of jobs and estimated that on average across the 21 OECD countries $9 \%$ of labor force are at risk of jobs [2]. The results showed that the risks of automation in the 21 OECD countries are much lower than the results in Frey and Osborne's occupation-based study [2]. However, the occupation risks vary from country to country. Differences between countries may reflect general differences in workplace organization, difference in previous investments into automation technologies and differences in the education of workers across countries [2]. The report concluded that it is mostly poorly qualified individuals who face a high risk.

Concerns regarding the automation and associated job risks have been seen repeatedly when a society faced with emerging technologies. In the first industrial revolution, the Luddite movements undertook destructive behavior against capitalists and engineers. Clark (2007) analyzed how the first industrial revolution had an impact on England society and clarified how social equalization and conciliation between different social positions were improved because of the industrial revolution, but the wage gap was significantly increased [27]. For economists, the Luddite movement was known as the "fallacy of Luddite" and the advanced technologies were acknowledged to be creators of employments and contributors to economic growth. However, from the side of business management, Ford (2009, 2015) concerns with the recent advancement of technologies that created the threats of automation and associated job risks [4-5]. In addition, the US government published the report of " Preparing for the Future of Artificial Intelligence" an analysis by the White House Council of 
Economic Advisors (CEA) [28]. The report noted that the negative effect of automation job risks will impact on lowerwage jobs, and also that AI-driven automation will increase the wage gap between less-educated and more- educated workers [28]. Although the CEA's report suggests that AI and machine learning have the potential to improve people's standard of living, the CEA's negative statements will have certain impacts on our society. Even though these studies are an analysis of developed countries, the results indicate that the corresponding automation risks would be seen in developing countries. The next section addresses the reasons why automation issues are related to economic growth in LDCs. the regional characteristics of the industrial structure through a comparison of the level of sophistication of exports.

\section{REGIONAL SOPHISTICATION OF EXPORTS}

Lall et al., (2005) developed a method of classifying exports based on their level of technology and level of sophistication. The technology level is defined as the Research and Development intensity of the core industrial process and the sophistication level is based on the average income of the exporter of a product [29]. Because of a web of complex globalized networks, developing countries are taking part in assembling high-tech products. They are not simply classified a high-tech products, which reflect higher skill and technologies.

Table 2: Regional sophistication of exports [29]

\begin{tabular}{lrc}
\hline \multicolumn{1}{c}{ Region } & 1990 & 2000 \\
\hline N America & 84.06 & 74.47 \\
W Europe & 80.86 & 71.88 \\
LAC1(including Mexico) & 69.14 & 64.91 \\
E Asia2 (excluding PRC) & 69.95 & 64.83 \\
E Asia1 (including PRC) & 69.18 & 62.78 \\
LAC2 (excluding Mexico) & 65.87 & 61.28 \\
SSA1(including South Africa) & NA & 59.55 \\
SSA2(excluding South Africa) & 59.17 & 55.93 \\
MENA & 62.60 & 55.72 \\
S Asia1(including India) & 58.53 & 50.68 \\
S Asia2(excluding India) & 53.51 & 39.73 \\
\hline
\end{tabular}

Notes: There is no export data for South Africa for 1990. South Asian data for 2000 includes exports data for 2001 for Bangladesh and Sri Lanka, which are missing 2000 data.

Table 2 shows the results of Lall and associate (2005) investigation of export sophistication scores by region in 1990 and 2000. Although the score decreases from 84.06 in 1990 and 71.88 in 2000, North America has the most sophisticated industrial structure [29]. The second highest score is in Western Europe, which gained a score of 80.86 in 1990 and 71.88 in 2000
[29]. East Asia excluding China ranks as fourth. East Asia including China has the fifth score but there is a little difference between third and fifth. The lowest score foes to South Asian countries namely Pakistan, Bangladesh, and Sri Lanka, where the score is 53.51 in 1990 and 50.68 in 2000 [29]. South Asia including India is ranked second from the bottom.

The results show that all developing regions have lower sophistication scores, compared with the two highly industrialized regions, North America and Western Europe. Moreover, the results also indicate that the automation risks in developing regions are higher than those of the developed countries because of their less sophisticated levels of industrialization. South Asia excluding India faces the highest automation risks. In the next section, the Asian economic status quo is described in more detail.

\section{TRAJECTORIES OF THE EAST AND SOUTHEAST ASIAN ECONOMY}

\subsection{Trajectory of the economic development}

Since the 1960s, four waves of economic growth have been seen in Eastern Asia [30]. The first wave started in Japan. The Japanese government prioritized economic growth during the re-construction period following the end of World War II and achieved rapid urbanization and industrialization during the 1960s and 1970s. Following Japan, the so-called newly industrializing economies (NIEs) of Asia, which consists of South Korea, Taiwan, Hong Kong, and Singapore, emerged as a second wave around the 1980s. The third wave came from the ASEAN countries such as Thailand, Malaysia and Indonesia. In the fourth wave, China and Vietnam have achieved rapid economic growth since the 1990s.

Figure 1 presented the GDP growth rates from 1960 to 2016 in selected Asian countries based on the data provided from World Bank [31]. Figure 1 shows the influences of the Asian currency crisis in 1998 and the world financial crisis of 2007-2008 clearly. Moreover, China and India present remarkable achievement and have become a driving force for world economic growth over a decade. The economic growth rate in China and India from 2000 to 2016 is $9.42 \%$ and $7.08 \%$ respectively [31]. According to the World Bank report (2017), China established a strategy for the industrial structural adjustment, which means China gradually shifted from the labor-intensive industry to high tech industry [32]. As a background to these changes, Chinese manufacturing wages rose by $281 \%$ from 2003 to 2010 [32]. Also, this implies the Chinese markets matured from production to consumption.

As East and Southeast Asian economy grows, extreme poverty rates have improved remarkably. According to the Millennium Development Goals report of 2015, the extreme poverty rate in Eastern Asia was reduced from 61\% in 1990 to only $4 \%$ in 2015 [33]. The rates in South-Eastern Asia reduced from $52 \%$ to $17 \%$. In addition, the proportion of people in vulnerable employment in East Asia has dropped from $71.2 \%$ in 1991 to $39.6 \%$ in 2015 [33]. 
Figure 1 The GDP growth rate (annual \%) in selected Asian countries

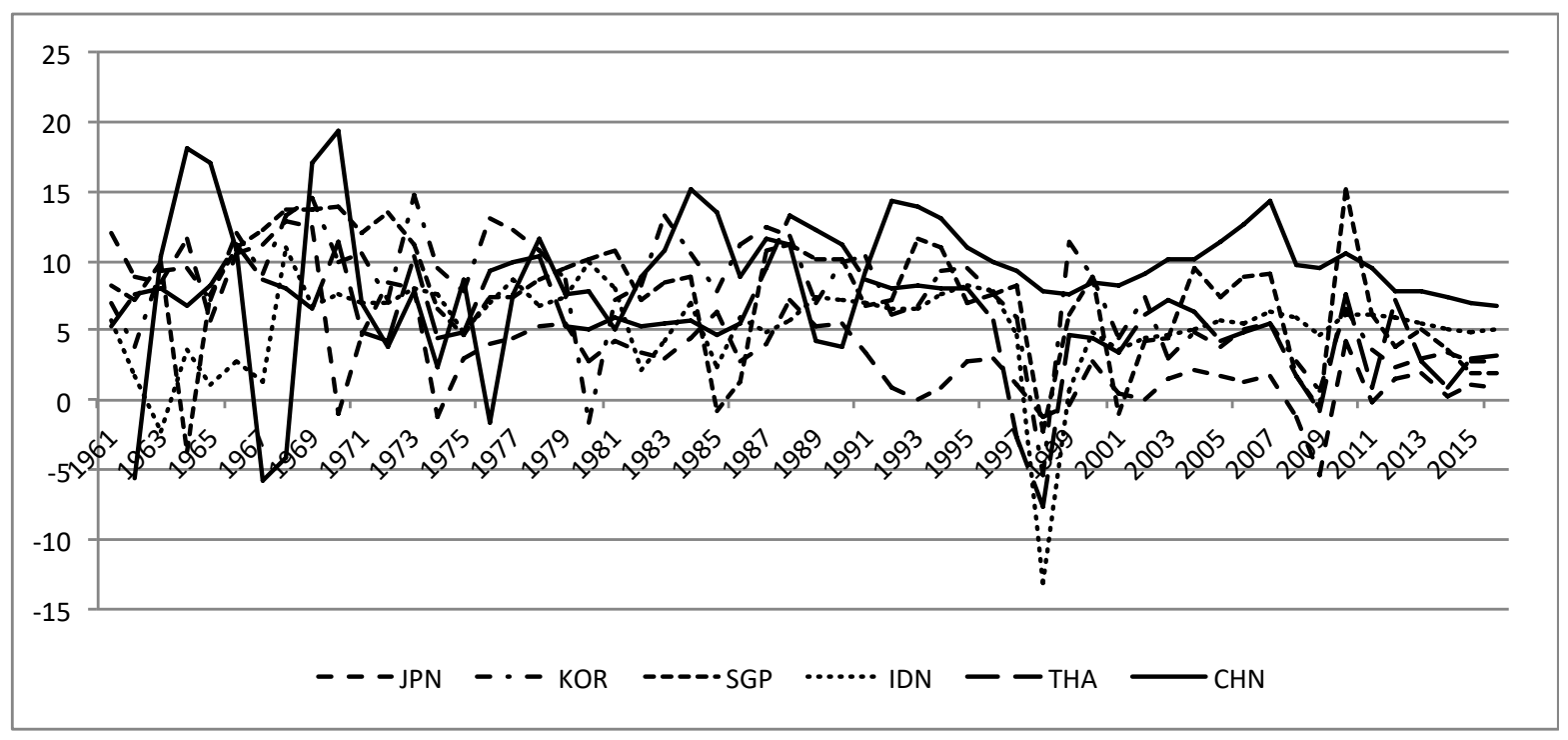

Data source: World Bank [31]

Among them, Bangladesh is one of the countries improved the living standards. Bangladesh recognized as an LDC since Bangladesh became independent from Pakistan in 1971 and received international aid for a long time. The World Bank reported Bangladesh, Kenya, Myanmar, and Tajikistan have become lower-middle income countries [34]. This indicates that their range of annual income has been upgraded from $\$ 1,046$ to $\$ 4,125$ [34]. According to the competitive industrial performance index of the United Nations Industrial Development Organization (UNIDO), Bangladesh's ranking has improved comparatively from the 102nd place in 1990 to the 77 th place in 2015 , although the top five manufacturing sectors still consist of low-tech industries: wearing apparel (35.5\%), textile (14.1\%), basic metals (13.3\%), food and beverages (12.0\%), and non- metallic mineral products (7.1\%)[35]. Fujita (2005) noted that the driving force of economic growth in Bangladesh depended mainly on the manufacturing sector but improvement of agricultural productivity played a basic role in the progress [36]. The main reasons were that as the food self-sufficiency rate rose, it became no longer anxious to eat, and as food imports from foreign countries decreased, it became possible to invest the surplus capital for domestic investment [36]. In addition, microcredit, in which the Grameen Bank developed provision of small secure loans as an instrument for poverty reduction, improved the ability of poor women in agricultural communities to manage their households [37]. It is an obvious fact that the market economy enhanced people's living standards; however, there is criticism of the problems that arise in a way of economic development because of the contradictions of poverty controls applied economic instrument and promoting market economy under the globalization. Collier (2007) noted that economic growth usually does benefits ordinary people and it is exceptional if only some people enjoy the benefits of economic growth [38]. It is controversial but we need to recognize what benefits economic growth has brought people. In addition, the digitalization technologies might aggravate the opportunities to get out from the low-income country as typified by Bangladesh.

\subsection{Background factors for the success of the East and Southeast Asian economies}

There is a question about how the East and Southeast Asian economy have been successful. To elucidate the mechanism of East Asian economic growth attracted attention as a research theme of many researchers in various fields. The World Bank (1993) reported that East Asian economic growth relied on foreign investment as a springboard for economic development and promoted expanding export opportunities [39]. Also the report pointed out that the effective use of prominent natural resources and human capital contributed to economic growth [39]. Krugman (1994) explained that the background factors contributing to East Asian economic growth were a high saving rate, forced labor migration from rural to urban areas, high educational attainment, and investment in physical capital [40]. On the other hand, Collier (2007) noted the importance of bureaucracy and political stability as contributors for Asian economic development [38]. For example, the people in the 
Philippines have a high level of education but their economy is still stagnant owing to the unstable political situation. Moreover, he added that institutional corruption would be regarded as the major factor obstructing the economic growth and effective bureaucratic organizations that are necessary for the economy to operate efficiency. Johnson (1982) focused on the role of bureaucracy in Japanese industrial policy, especially with Ministry of International Trade and Industry (MITI) and analyzed the mechanism of MITI from the viewpoint of history and organization [41]. Japan's industrial policy had major influence on some other Asian countries. Perkins (2013) explained the Asian economic growth based on the perspectives of cultural foundation, role of government, industrial and agricultural policies [42]. Another distinctive factor is regional economic integration in the goods sector. As a sequel of the report in 1993, the World Bank (2007) published "An East Asian Renaissance" and noted regionalization is a key to explain trade, finance, and innovation accelerating within East Asia since the late 1990s [43]. Okamoto (2005) noted that intra-industrial trade within the open trade system in ASEAN contributed to the regional economic connection and economic growth [44]. For example, Viet Nam enjoys a high level of foreign investments and receives benefits from entering the global value chain; meanwhile, Cambodia and Laos have failed to catch up [44].

\section{MOVE TOWARD DIGITAL MODERNITY AND ESTABLISHMENT OF NEW INTERNATIONAL PRINCIPLES}

\subsection{Transition from Industrial Modernity to Digital Modernity}

What did digital technologies bring to our sight so far? For instance, they are able to duplicate products without loss of quality. We have already seen this through streaming services for music, movies, and books. IoT is shape-shifting the products and nature of electronic appliances. Its influences range from commodities (smart phone, smart watch, autonomous vehicle, etc.) to built environment (smart houses and smart buildings) and infrastructure (smart cities). AI has already become an influential player in our society and it is no longer merely science fiction. We use AI in everyday life, such as the Apple Siri, Amazon Echo, Google Home, etc. These products allow us to feel the future and promote $\mathrm{AI}$ as a pleasant neo-futuristic technology. Moreover, digital technologies will step into a new realm. For example, the characteristics of block chain are credibility, transparency, and openness. It is therefore used to transfer Bit coins, but another face of block chain is it has abilities to wipe out the inter-mediators in either the public or private sectors. If block chain technology is applied to the private sector, organizational work will be more pared down and efficient. This will impact on the structural reform. As just described, the digital technologies are developing rapidly and pervading every aspect of our lives in unexpected ways. Moreover, the promotions of IoT, AI, block chain, etc. have huge potentials to change human work roles. These imply that our society is entering a transition period between industrial modernity and digital modernity. Beck et al. (1994) noted that the last transition was from traditional modernity to industrial modernity. In this process, the modern society is undercutting its formation of class, stratum, occupation, sex roles, nuclear family, plants, business sectors and forms of natural technoeconomic progress [45]. In addition, the side effects have seen as environmental deterioration caused by firms' pollution emissions and many victims suffered from pollution-related diseases. Developing countries in the middle of industrialization are still suffering from pollution emissions. Beck noted that these are the destructions that allow advancement to the next step, and then, the reconstructions for the new structural formation start in the next phase. This process is defined "reflexive modernization" [45] and referred to the advent of risk society [46]. The same is predicted for the transition toward the digital modernization. In the course of digital modernization, the side effects will induce both social and economic destruction of which jobless risks related to the digital technologies are one example.

\subsection{The Dilemma for Globalization}

The trajectory of East and Southeast Asian development was deeply related to Western diplomatic policies, especially during the Cold War period. In the aftermath of World War II, the United States led the way to an extraordinary achievement in the world order based on a sense of responsibility, strategies to promote state power, and moral universalism for freedom and democracy [47]. In addition, the United States promised prosperity and freedom to the countries that belonged to the Western Bloc in order to maintain a liberal system. During the postwar reconstruction period, the Marshall plan was successfully introduced to rebuild the Europe as well as strengthen United States, militarily, economically, and politically [48]; under the Bretton Woods Agreement, several international economic institutions such as IMF and World Bank were established to stabilize the world economy. Moreover, international aid efforts were targeted at the expansion of democracy, and encouraging independence from colonial occupation. Indeed, Western society tried to support developing countries to prevent them from being incorporated into the communist orbit through free world trade. During the 1960s, "Taylorism" was a main engine for the capitalist society and also a showcase for a prosperous lifestyle, supported by mass production and mass consumption. At the same time, liberalization was a basic principle and direction for the postwar institutional framework regulating global trade and financial activities [49]. The General Agreement on Tariff and Trade (GATT) made progress in the liberalization of trade because protectionism was thought to be one of the factors that caused World War II. In addition, free trade agreements, namely NAFTA, ASEAN, APEC, MERCOSUR were negotiated through multinational cooperation and concluded as international conventions, and promoted the expansion of world economy. As described above, the success of the East and Southeast Asia's 
Economic Growth and Automation Risks in Developing Countries Due to the Transition Toward Digital Modernity

economies depended greatly on the establishment of networks of free trade agreements. A policy of openness removed the trade barriers and promoted circulation of economic inputs and outputs at the regional level and also contributed to poverty reduction through economic prosperity. However, recent studies have pointed out the adverse effects of the free trade system under the globalization, by examining how such globalization promoted economic disparity for a long time. Stiglitz (2002) described that although globalization has contributed to improve the poverty reduction and living standards for people in developing countries, some trade rules set by international institutions, which authorize globalization, have many disadvantages to developing countries and lead to the economic disparity [50].

\subsection{Coexistence and A New framework for International Principles}

It is assumed that all goods and services that both developed country and developing countries have produced will be replaced by automation and will no longer function like current manufacturing; this might make it difficult to sustain the current trade system.

Since the solutions for developed countries have been discussed widely, this study especially focuses on the problems for developing countries; one is to return to an economic system that imposes high tariffs and restores protectionism as in the past; the second is to introduce a global level taxation system such as global consumer tax, global robotics tax, global corporate tax, and so on, collected from the technological advanced countries to distribute to developing countries. It is hard to introduce the former solution because perfect closed system will be difficult realized and history taught us prewar protectionism created the vicious economic circle and became one of the factors in causing World War. The latter one is applicable but it must obtain all parties agreement. They are only hypothetical solutions given the current situation. Even so it is critical for our society to provide alternative principles by which to co-operate on the North-South problem. Also, the principles have to be endowed with the sharing value between developing and developed countries [51-52]. In the aftermath of the World War II , western society tried to support developing countries by maintaining the principle of a free world system, which contributed to poverty reduction through socioeconomic development based on a policy of openness. With the end of the Cold War, defense of the free world has lost its significance but economy is getting more important political instrument to stabilize bilateral relations. In today's powers, important consideration is internal economic and social development than external conquest [48]. In addition, internal development requires not only external stability but also relationships that contribute to economic development [48]. However, advancement of automation technologies might aggravate opportunities for developing country and, as a result, they might affect interdependency between developing and
ICEGOV'18, April 2018, Galway, Ireland

developed countries, which accumulated through the long-term international aid.

International society needs to establish a form of a stewardship and principles to embody the responsibilities and morality that can ensure poverty reduction as well as preventing automation risks for developing countries. This study also suggests that the next principle is not just speculation on the part of the West bloc alone; it is better to begin with a first step that allows both developed and developing countries to decide the future through meaningful discussion about principles. Moreover, it is necessity for our society to establish new international rules for mitigating negative effects of the digitalization in order to reduce economic disparity.

\section{CONCLUSIONS}

Our society is facing a transition period from industrial modernity to digital modernity. The digital technology is changing our society and occurring rapidly in unforeseen ways. During this period, the changes may be inevitable and unexpected side effects may occur in the near future. A review of the literature suggests that in developing countries, law qualified individuals in developed countries will face the risks of jobs that may be highly subject to automation. This might be a side effect of the transition toward digitalization. In addition, corresponding risks will be seen in developing countries because of their less sophisticated levels of industrialization. The rise of automation and digitalization might take over the developing country's opportunities to elevate from low-income country to middle or high-income country. To take the case of Bangladesh as an example, it took a long time to become a lower-middle income country. There were several factors that contributed to Bangladesh's economic success such as increasing self-sufficiency in food, international aid, educational attainment, and microcredit, but the factor that contributed the most was manufacturing. Other East and South East Asian countries are the same as Bangladesh. Also, manufacturing will no longer provide the same dual benefits of productivity gains and job creation for the low skilled labor [32]. Moreover, the fourth industrial revolution will lead to reinforcing of the economic disparity between nations.

In the aftermath of World War II, western society tried to support developing countries in maintaining the principles of a free world system based on the political and economic intention. East and Southeast Asia is one of them. Previous study showed that the success of East and Southeast Asia's economy related to various factors. Among them, foreign investment, program of tariff cuts, and import liberalization are specifically supported by the principle of maintaining free world and played critical roles for the economic development. East and Southeast Asian countries would not have received such sufficient aids unless it was a Cold War period. However, defense of the free world has lost its significance since the end of the Cold War. On the other hand, economy is becoming more important political instrument for enhancing interdependency. Although our 
society enjoys the benefits brought on by globalization, reflecting on advancing globalization shows a contradiction, as it led to economic disparity and caused serious social damages in the developing world. We need to introduce alternative principles for developing countries to solve the digitalization problems. It is necessary to avoid the situation where human beings work below the cost in order to maintain robots. Multilateral economic relationships have become stronger than before, and have also been imbued with politically and socially important meaning. Moreover, both developing and developed countries need to share their values through meaningful discussion and change their rules and principles to be more adaptive in the transition to digital modernity. This study suggests that international society establish a stewardship that will embody the responsibilities and morality necessary to prevent the risks of automation faced by developing countries.

\section{REFERENCES}

[1] Frey C. Benedikt and Michael A. Osborne. 2013. The Future of Employment: How Susceptible are Jobs to Computerization?. Oxford Martin program on technology and employment. DOI: http://www.oxfordmartin.ox.ac.uk/downloads /academic /The_Future_of_Employment.pdf

[2] Arntz, M. and Gregory, T. 2016. The Risk of Automation for Jobs in OECD Countries: A Comparative Analysis", OECD Social, Employment and Migration Working Papers, No. 189, OECD Publishing, Paris.

[3] Klaus Schwab. 2016. The Fourth Industrial Revolution. World Economic Forum, Geneva, Switzerland.

[4] Ford Martin. 2015. The Rise of the Robots: Technology and the Threat of Mass Unemployment. Oneworld publications.

[5] Ford Martin. 2009. The Lights in the Tunnel: Automation, Accelerating technology and the Economy of Future. Accurant Publish.

[6] Gordon, J. R. 2016. The rise and fall of American growth: The U.S standard living since the civil war, Princeton University. Princeton, Oxford.

[7] Brynjolfsson Erick. and McAfee Andrew. 2011. Race Against the Machine. How the digital revolution is accelerating innovation, driving productivities, and irreversibly transforming employment and the economy, Digital Frontier Press.

[8] Brynjolfsson Erick. and McAfee Andrew. 2014. The Second Machine Age: Work, Machine, and Prosperity in a time of brilliant technologies. W.W. Norton \& Co Inc., New York, London.

[9] Buhr D. Social Innovation Policy for Industry 4.0. FRIEDRICH EBERT STIFTUNG . www.fes-2017plus.de.

[10] The Industrie 4.0 Working Group. 2013. Recommendations for implementing the strategic initiative INDUSTRIE 4.0.

http://www.acatech.de/fileadmin/user_upload/Baumstruktur_nach_Website /Acatech/root/de/Material_fuer_Sonderseiten/Industrie_4.0/Final_report_I ndustrie_4.0_accessible.pdf

[11] Whitehouse https://obamawhitehouse.archives.gov/the-press-office/2011/ 06/24/president-obama-launches-advanced-manufacturing-partnership

[12] Jin, Jianmine. Reading "Made in China 2050" strategy for advancing Chinese industries. http://www.fujitsu.com/jp/group/fri/en/economic/publications/ report/2017/report-440.html

[13] ICT for manufacturing: Action plan T roadmap for manufacturing 2.0. https://setis.ec.europa.eu/energy-research/sites/default/files/staticprojects/files/roadmap.pdf

[14] innovate UK. https://www.gov.uk/government/uploads/system/uploads/ attachment_data/file/631065/17.3172_Innovate_UK_Annual_Report_and_Ac counts_2016_to_2017.pdf

[15] British Embassy Tokyo, department for International trade. 2016. Innovation is Grete. Britain \& Northern Ireland. " The latest trends of IoT in England".

Rethink robotics. http://www.rethinkrobotics.com/videos/

[16] Industry of Future. https://www.economie.gouv.fr/files/files/PDF/pk_industry-of-future.pdf.

[17] Growth strategy 2017. https://www.kantei.go.jp/jp/singi/keizaisaisei/ kettei.html

[18] New robot strategy. https://www.kantei.go.jp/jp/singi/keizaisaisei/pdf/ robot_honbun_150210EN.pdf

[19] Rethink Robotics. http://www.rethinkrobotics.com
[20] Cyberdyne. HAL. https://www.cyberdyne.jp

[21] irobot. http://www.irobot.com

[22] Ross Alec. 2017. The Industries of The Future. Simon \& Schuster. New York, London, Toronto, Sydney, New Delhi.

[23] The Doudna Lab. http://rna.berkeley.edu/crispr.html

[24] Kobayashi, Masakazu., Genome henshutohananika: DNA nomesu CRISPR no Shogeki, Kodanshagendaishinsho. (printed in Japanese)

[25] OXITEC, http://www.oxitec.com.

[26] Center for iPS cell research and application, Kyoto University, http://www.cira.kyoto-u.ac.jp/e/index.htm

[27] Clark, Gregory. 2008. A Farewell to Alms: A Brief Economic History of the World. Princeton University Press.

[28] Executive office of the President National Science and Technology Council committee on Technology. 2016. Preparing for the Future of Artificial Intelligence.

https://obamawhitehouse.archives.gov/sites/default/files/whitehouse_files/ microsites/ostp/NSTC/preparing_for the future_of ai.pdf

[29] Sanjaya Lall, John Weiss and Jinkang Zhang. 2005. The Sophistication of Exports: A New Measure of Product Characteristics. ADB Institute Discussion Paper No.23. 1-28. DOI: https://www.adb.org/sites/default/files/publication/156775/ adbi-dp23.pdf

[30] Hiroshi Oikawa. 2000. Asia's Keisai Hatten to Nihon. Kazuhiro Igawa. Masayuki Hayashibara. Msao Satake. Kouji Aoki (Eds.). Kokusaikeizaigaku. Chuo Keizai sha, Tokyo, Japan. (printed in Japanese)

[31] The World Bank. https://data.worldbank.org

[32] The World Bank. Trouble in the MAKING? The future of manufacturing -led development. http://www.worldbank.org/en/topic/competitiveness/ publication/trouble-in-the-making-the-future-of-manufacturing-leddevelopment

[33] United Nations Millennium Development Goals 2015 . DOI: http:// www.un.org/millenniumgoals/2015_MDG_Report/pdf/backgrounders/MDG \%202015\%20PR\%20Bg\%20Asia.pdf

[34] The World Bank http://www.worldbank.org/en/news/pressrelease/2015/07/01/new-world-bank-update-shows-bangladesh-kenyamyanmar-and-tajikistan-as-middle-income-while-south-sudan-falls-backto-low-income

[35] United Nations Industrial Development Organization, UNIDO Statistical Data Portal. DOI: http://stat.unido.org/country-profile/economics/BGD.

[36] Koichi Fujita. 2005. Bangladesh Nousonkaihatsu no nakano Kaisohendo. Kyoto University Press, Kyoto, Japan. (printed in Japanese)

[37] Grameen bank. http://www.grameen.com

[38] Paul Collier. 2007. The Bottom Billion: Why the poorest countries are failing and what can be done about it. Oxford University Press, Oxford, UK.

[39] The World Bank. The East Asian Miracle: Economic Growth and Public Policy - A The World Bank Policy for Research Report. Oxford University, Oxford, UK.

[40] Paul Krugman. 1994. The Myth of Asia's Miracle. Foreign Affairs, 73, 6, 6278.

[41] Chalmers Johnson. 1982. MITI and the Japanese Miracle: The Growth of Industrial Policy, 1925-1975. Stanford University Press, United States.

[42] Dwight H. Perkins. 2013. East Asian Development: Foundations and Strategies. Harvard University Press, Cambridge, Massachusetts, London.

[43] Deepak Bhattasaki. Milan Brahmbhatt. Gaurav Datt. Mona Haddad. Edward Mountfield. Radu Tatucu. Ekaterina Vostroknutova 2007. An East Asian Renaissance: Ideas for Economic Growth. The International Bank for Reconstruction and Development / The World Bank, Washington D.C, United States

[44] Yumiko Okamoto. 2005. Emergence of the Intra-Mediate Trade: Implications for the Asia-Pacific Region. Paper presented at the East-West center and the Rosenberg Institute of Global Finance Brandeis University. DOI: www.eastwestcenter.org/fileadmin/.../PAFTAD_30_Okamoto.pdf

[45] Beck, Ulrich., Giddens, A. and Lash, S. 1994. Reflexive modernization: politics, tradition and aesthetics in the modern social order. Polity Press. UK. or responsible innovation. Research Policy, 42, 1568-1580.

[46] Beck, Ulrich. 1992. Risk Society: Towards a New Modernity, Sage Publications. London, Thousand Oaks, New Delhi.

[47] Henry Kisshinger. 2015. World Order. Penguin Books, New York, United States.

[48] Richard Haass. 2017. A World in Disarray: American Foreign Policy and the Crisis of the Old Order. Penguin Press, New York, United States.

[49] Satoshi Ikeda. 1996. World Production. Terence K. Hopkins and Immanue Wallerstein (Eds.). The Age of Transition. Zed Books, London, UK

[50] Joseph E. Stiglitz. 2003. Globalization and its discontents. Penguin, New York, United States.

[51] P. Macnaghten, R. Owen, J. stilgoe, B. Wynne, A. Azevedo, A. de Campos, J. Chilvers, R. Dagnino, G. di Giulio, E. Frow, B. Garvey, C. Groves, S. Hartley M. Knobel, E. Kobayashi, M. Lehtonen, J. Lezaun, L. Mello, M. Monteiro, J. 
Economic Growth and Automation Risks in Developing

Countries Due to the Transition Toward Digital Modernity

ICEGOV'18, April 2018, Galway, Ireland

Pamplona da Costa, C. Rigolin, B. Rondani, M. Staykova, R. taddei, C. till, D.

tyfield, S. Wilford and L. Velho. 2014. Responsible innovation across

borders: tensions, paradoxes and possibilities. journal of Responsible

Innovation, 1(2). 191-199.

[52] Jack Stilgoe. Richard Owen. and Phil Macnaghten. 2013. Developing a framework for responsible innovation. Research Policy, 42, 1568-1580. 